\title{
Mechanical Properties of Sandwich Composites Reinforced by Nanoclays: An Overview
}

\author{
João Parente ${ }^{1}$, Paulo N. B. Reis ${ }^{1}$, , M. Neto ${ }^{2}\left(\mathbb{C}\right.$ and A. M. Amaro ${ }^{2, *(\mathbb{C}}$ \\ 1 C-MAST, Department of Electromechanical Engineering, University of Beira Interior, Calçada Fonte do \\ Lameiro, 6201-100 Covilhã, Portugal; joao.miguel.parente@ubi.pt (J.P.); preis@ubi.pt (P.N.B.R.) \\ 2 Department of Mechanical Engineering, University of Coimbra, Center for Mechanical Engineering, \\ Materials and Processes (CEMMPRE), 3030-788 Coimbra, Portugal; augusta.neto@dem.uc.pt \\ * Correspondence: ana.amaro@dem.uc.pt; Tel.: +351-239790764
}

Received: 23 March 2020; Accepted: 9 April 2020; Published: 10 April 2020

\begin{abstract}
Structural sandwich composites have been widely used in many engineering applications, and this trend continues due to their superior mechanical properties, thermal insulation and acoustic damping. However, to further improve their mechanical properties, literature reports significant benefits obtained with nano-reinforcements. In this context, nanoclays are the most popular nano-reinforcements for polymeric nanocomposites, due to their relatively high ion exchange capacity, high aspect ratio and economic advantages. In order to stablish a systematic understanding for design criteria, this work intends to summarize all studies present in the open literature about this topic. It was possible to conclude that using nanoclays improves the mechanical properties of structural sandwich composites, especially in terms of impact strength. Nevertheless, the benefits obtained regarding fatigue performance are not adequately reported in the literature, revealing the need to develop these studies.
\end{abstract}

Keywords: nanoclay; sandwich composites; mechanical properties

\section{Introduction}

Sandwich composites are structures made of rigid outer layers-also known as skin-and an inner layer, known as the core. Several works describing the various materials used in sandwich composites are reported in literature. In terms of skins, for example, they are composed mainly of fiber-reinforced polymers (matrices like epoxy, PEEK, polyamide and fibers like glass, carbon or aramid fibers), metals alloys (such as aluminum, steel and titanium) and natural materials (such as wood, pine and other types of cellulose based materials). On the other hand, the core is essentially composed of non-rigid and low-density elastic materials, such as foam core, honeycomb structures or balsa wood [1-8]. Building composite structures with these two types of materials make it possible to design structural components with good outer-layer mechanical properties, and simultaneously, good impact and vibration tolerances within the core layer, making them good options for aerospace, marine and wind power industries $[9,10]$.

In order to improve the performance of sandwich composites, it is possible to add nano reinforcements to the base material. One such nano reinforcement often used is nanoclay (NC), which is a new generation of processed clay composed mainly of silicon dioxide $\left(\mathrm{SiO}_{2}\right)$ and aluminum oxide $\left(\mathrm{AlO}_{6}\right)$ in different proportions, depending on the type. There are three main types of nanoclays: kaolinite, with a proportion of $1: 1$ of $\mathrm{SiO}_{2}$ and $\mathrm{AlO}_{6}$, respectively; montmorillonite, with a 2:1 proportion; and chlorite, with a 2:2 proportion [11]. Montmorillonite is the nanoclay most used in this type of application because it offers a high aspect ratio and high swelling properties [11]. Nanoclays improve 
sandwich composite performance and can be mixed with resin or foam in the outer or inner layers, respectively, depending on the desired characteristic that needs to be improved.

Considering that the first research work involving nanoclays in sandwich structures was published only in the late 2000s, this work aims to provide an overview of all studies available in the open literature, as well as the benefits discussed, in terms of their incorporation into the core or skin.

\section{Sandwich Composites Incorporating Nanoclays into the Core}

The presence of nanoclays can modify the characteristics of a sandwich material, but the benefits obtained depend on their incorporation at the core or skin level. When they are added at level of foam core, for example - a material with low density and weak mechanical characteristics-improvements in toughness and impact performance are achieved. When the core is composed of foam materials, they give the composite structure an insulating property, while fiber-reinforced resins induce better impact properties. For example, Figure 1 shows the benefits of nano-enhanced resins on the impact response of sandwich composites involving fiber glass/epoxy skins and balsa wood core.

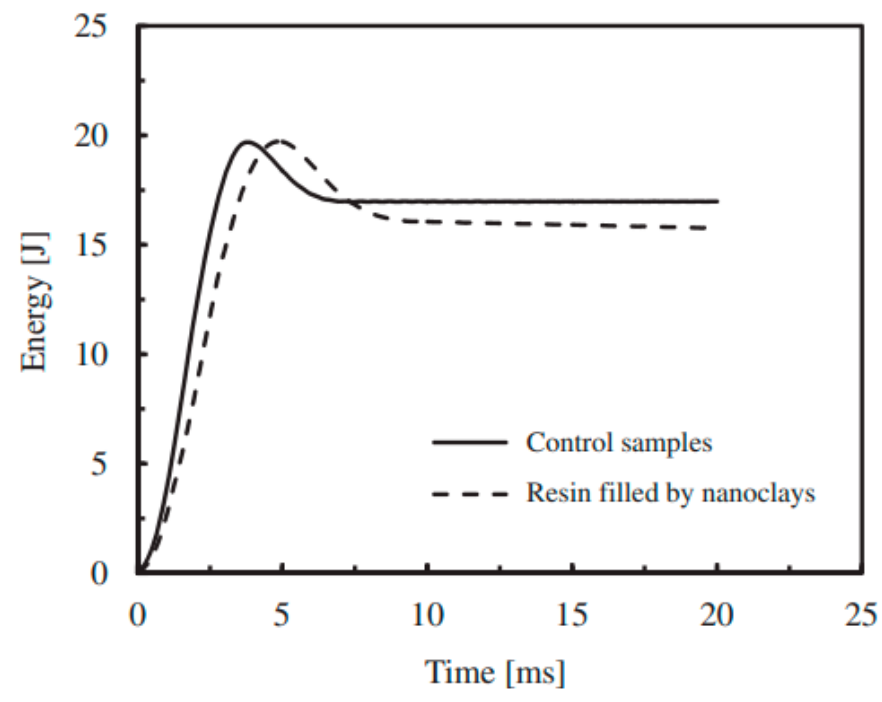

Figure 1. Energy versus time curves for sandwiches with epoxy resin and epoxy filled by nanoclays (impact energy of $20 \mathrm{~J}$, sandwich composite made by fiber glass/epoxy skins and balsa wood core) [12].

Several authors have studied the benefits obtained from the incorporation of nanoclays into the core of sandwich composites, especially in terms of impact strength.

For example, one of the first studies reported in the open literature about the effect of nanoclays in sandwich structures was published in 2005 by Gupta et al. [13]. They mixed nanoclays with resin and glass microballoons, in order to create a syntactic foam with three different densities of microballoons $\left(220,320\right.$ and $\left.460 \mathrm{~kg} / \mathrm{m}^{3}\right)$ and two different quantities of nanoclays $(2 \mathrm{wt} \%$ and $5 \mathrm{wt} \%)$. The results showed that the compressive strength decreased between 10 and $20 \%$ when $2 \mathrm{wt} \%$ of nanoclays were added, while for $5 \mathrm{wt} \%$, the compressive strength behaved like the control group. The toughness results showed an increase of $80 \%$ and $125 \%$ for $2 \mathrm{wt} \%$ and $5 \mathrm{wt} \%$ of nanoclays and a microballoons content of $220 \mathrm{~kg} / \mathrm{m}^{3}$. In the case of medium density foams $\left(320 \mathrm{~kg} / \mathrm{m}^{3}\right)$, there was an increase of $150 \%$ and $200 \%$ for 2 and $5 \%$ of nanoclays, respectively, while in high density foams $\left(460 \mathrm{~kg} / \mathrm{m}^{3}\right)$ the increase in toughness was $125 \%$. Authors explained that the addition of nanoclays increased the plasticity of the material and, consequently, the number of fractures produced under compression decreased [13].

In 2008, Saha et al. [14] compared the debond fracture toughness of sandwich structures, considering different types of nanoparticles (nanoclays, carbon nanofibers and multi walled carbon nanotubes) added to the polyurethane foam core. For each type of nanoparticle, they compared three different contents: $0.5 \mathrm{wt} \%, 1 \mathrm{wt} \%$ and $1.5 \mathrm{wt} \%$ [14]. The performance of these materials was evaluated 
using the tilted sandwich debond test-similar to the double cantilever beam test, but performed on an inclined surface-in order to obtain face/core debonding, as opposed to the crack deflection into the core, i.e., to assure the crack propagation trough the interface [14]. From these tests, it was possible to conclude that the best improvement of debond fracture toughness was obtained with $1 \mathrm{wt} \%$ of nanoclays, but further increasing nanoparticles resulted in a decrease of debond fracture toughness. Authors explained this behavior by the effects of size and aggregation/agglomeration of nanoparticles on the interfacial/interphase properties [14].

Hosur et al. [15], in 2008, analyzed the response to low-velocity impact loading of sandwich composites containing nanoclays. They were mixed with an epoxy resin to cover the carbon fiber outer layer, while the inner layer was composed of foam with nanoclays. Two content of nanoclays were used for the outer layer ( $1 \mathrm{wt} \%$ and $2 \mathrm{wt} \%)$, and two other contents $(0.5 \mathrm{wt} \%$ and $1 \mathrm{wt} \%)$ for the core layer. Impact tests were performed using a drop weight testing machine; three different impact energies $(15,30$ and $45 \mathrm{~J})$ were considered. The results showed that the samples with nanoclay insertions in the foam core exhibited higher peak loads than those produced with the neat foam core. The damage analysis also showed that, after the impact tests, the damaged area was lower for samples with nanoclays. While in neat samples the energy was absorbed by the collapse of the foam cells and by shear fracture, the samples with nanoclays failed due to the brittle fracture of the cells [15].

In 2008, Robinson et al. [16] studied the addition of nanoclays (between $0 \mathrm{wt} \%$ and $2 \mathrm{wt} \%$ ) to a polyurethane foam for application in sandwich composites. The benefits were analyzed in terms of compressive, flexural and dynamic properties. They observed that the addition of nanoclays improved the storage modulus, as well as the glass transition of the material up to $0.5 \mathrm{wt} \%$. For compression and flexural tests, the best results were achieved for $0.5 \mathrm{wt} \%$ and $1 \mathrm{wt} \%$ of nanoclays, respectively [16].

In 2009, Saha et al. [17] compared the bending and thermal behavior of syntactic foams with and without nanoclays. The content of nanoclays used ranged from $0 \mathrm{wt} \%$ to $3 \mathrm{wt} \%$. Regarding the flexural properties, they increased with the addition of nanoclays up to $2 \mathrm{wt} \% \mathrm{wt} \%$, with values around $42 \%$, $38 \%$ and $18 \%$ for flexural strength, flexural strain and flexural modulus, respectively. Higher contents promoted agglomerations and, consequently, lower bending properties were observed [17]. In terms of dynamic properties, similar behavior was observed, where the maximum modulus and loss modulus were obtained for $2 \mathrm{wt} \%$ of nanoclays. Compared with the values obtained for neat samples, $2 \mathrm{wt} \%$ of nanoclays promoted increases of $30.3 \%$ and $27.8 \%$, respectively, for modulus and loss modulus.

In 2009, Woldensenbet et al. [18] published a study where the flexural properties of sandwich structures produced with syntactic foam enhanced by nanoclays were evaluated. Two different densities of microballoons ( 220 and $460 \mathrm{~kg} / \mathrm{m}^{3}$ ) were mixed with a constant content of $1 \mathrm{wt} \%$ of nanoclays. Three and four-point bending tests were performed to compare the bending properties of the materials. These authors concluded that the incorporation of nanoclays in the foam core increased the shear stress and facing bending stress of the material, because more energy was needed to separate the interfaces. In this case, multiple cracks were observed with the presence of nanoclays, evidencing the brittleness of the material, but also due to the difficulty of crack propagation with the presence of nano-reinforcements [18].

In 2010, John et al. [19] studied the mechanical properties of cyanate ester synthetic foams containing $2 \mathrm{wt} \%$ and $4 \mathrm{wt} \%$ of nanoclays. Tensile, flexural and compressive properties were evaluated-as well as the dynamic and thermal properties of the materials. An increase in tensile, flexural and compressive strength was observed with the content of nanoclays in the foams. In terms of compressive strength, increases of around $73 \%$ and $150 \%$ were observed when $2 \%$ and $4 \%$ of nanoclays were added to the syntactic foams, respectively, while the tensile and bending strengths increased about by $63 \%$ and $94 \%$, and $55 \%$ and $97 \%$, respectively. This increase was justified by the presence of nanoclays, because they provided higher interaction areas with the matrix, and restricted the mobility of polymer chains and, consequently, the crack propagation through the material [19].

In 2011, Njuguna et al. [20] characterized a sandwich material composed of a polyurethane/layered silicate foam core and aluminum skins. Nanoclays were added to the foam in contents ranging from 
$0 \%$ to $7.5 \mathrm{wt} \%$, and impact tests were performed using a drop weight testing machine with an energy of $45 \mathrm{~J}$. The best impact performance was obtained for specimens with $7.5 \mathrm{wt} \%$ of nanoclays.

In 2011, Hossain et al. [21] produced a green sandwich composite material composed of a jute skin and a biopol core enhanced by nanoclays (between $0 \mathrm{wt} \%$ and $4 \mathrm{wt} \%$ ). They analyzed the dynamic and bending properties, as well as the moisture absorption of the materials. The best results achieved in all tests were obtained with the highest content of nanoclays. In terms of mechanical properties, the benefits observed were explained by the brittleness of the nanophased material, reducing the strain percentage, while the lowest moisture absorption is due to the nanoclays that acted as a moisture barrier and, therefore, did not allow the water to penetrate the material [21]. Similar tests were carried out with materials exposed to moisture, and the best results were obtained with samples enhanced by nanoclays. This evidence was explained by the lower water absorption of the nano-enhanced material.

In 2011, Demissie et al. [22] studied the mechanical performance of nanoclay-filled syntactic foams after immersion into salt water or de-ionized water. The weight fraction of nanoclays used in this study ranged from $0 \%$ to $5 \%$; the volume fraction of glass microballoons was around $60 \%$. After hygrothermal conditioning, the samples were subjected to high strain rate, compression and dynamic mechanical analysis tests. It was possible to conclude that the addition of nanoclays had a negligible effect on the uniaxial compressive properties, although some improvements were observed for samples with $2 \%$ nanoclays. Regarding the viscoelastic properties-and when compared to neat syntactic foam-the storage modulus and $\mathrm{T}_{\mathrm{g}}$ increased up to $2 \mathrm{wt} \%$ of nanoclays, regardless of whether the samples were dry or wet. However, exposures to salt water promoted the worst results due to the weakening of chemical bonds between polymer chains.

In 2013, Hossur et al. [23] evaluated the low velocity impact response of a sandwich composite produced by carbon fiber skins and polyurethane (PU) foam core. Three organically modified nanoclays (Cloisite ${ }^{\circledR}$ 10A, Cloisite ${ }^{\circledR} 30 \mathrm{~B}$ and Nanomer ${ }^{\circledR}$ I.28E) and maple wood flour were used as fillers for the PU foam core. Sandwich composites contained $0.5 \mathrm{wt} \%$ and $2.5 \mathrm{wt} \%$ of nanoclays and wood flour, respectively. The impact energies used were 10, 20 and $30 \mathrm{~J}$; the pneumatic rebound brake system prevented multiple impacts on the specimen. It was possible to conclude that, for energies up to $20 \mathrm{~J}$, the nanophasic core sandwiches had higher peak loads, however, when wood flour was incorporated instead of nanoclays, the peak load decreased in comparison to the neat cores. On the other hand, the peak load values obtained for $30 \mathrm{~J}$ did not show as much improvement as those observed for $10 \mathrm{~J}$ and $20 \mathrm{~J}$. The failure analysis evidenced extensive damage in all sandwiches for the energy of $30 \mathrm{~J}$, while for $10 \mathrm{~J}$ only penetration in the top facesheet and partial penetration of the core was observed. Regarding the sandwiches tested at $20 \mathrm{~J}$, authors observed delaminations at the interfaces between the core and facesheets, except for those involving organically modified nanoclays from Cloisite ${ }^{\circledR}$.

Later, in 2014, Sachse et al. [24] performed impact testes to evaluate the mechanical properties of sandwich panels with nanoclay-filled polyurethane foams and glass fiber-reinforced polyamide and polypropylene facesheets. Nano-enhanced foam cores with organophilic montmorillonite loadings between $0 \mathrm{wt} \%-10 \mathrm{wt} \%$ were produced for this study. All sandwich panels were subjected to low energy impact tests, in a drop weight testing machine with an energy of $15 \mathrm{~J}$, as well as compression tests to determine their quasi-static behavior. These authors achieved improvements in terms of absorption energy between $66 \%$ and $92 \%$ for sandwiches with polypropylene facesheets and $23 \%$ and $43 \%$ for sandwiches with polyamide facesheets. In terms of quasi-static tests, the usage of different facesheets showed a negligible effect on the compressive properties. However, for both materials, the compressive strength decreased with increasing filler loading. However, an increase in the compression modulus of $20 \%-37 \%$ was observed for sandwiches with polyamide facesheets. the authors explained this behavior by the reaction of the clay with the foam core matrix, which has weaker characteristics and leads to the creation of large voids. Regarding the impact results, they are inferior to those in the open literature due to the usage of foams with different number of cells.

Antunes et al. [25] evaluated the compression properties of a polyurethane foam incorporating variable concentrations of nanoclays (between 0 and $15 \mathrm{wt} \%$ ), as well as other reinforcements, such as 
metal wires and cellulosic-based reinforcements (esparto wool, cellulose pulp and cardboard paper). The compression tests were carried out on cylindrical specimens, using a Galdabini SUN 2500 testing machine, with a $25 \mathrm{kN}$ load cell at a constant speed of $5 \mathrm{~mm} / \mathrm{min}$, according to ISO 844 . It was possible to conclude that the addition of nanoclays improved the compression properties of the foam and the addition of metal wires further improved these properties. In fact, the density of the foam increased with the addition of nanoclays, which increased even more with the metal wires, promoting the benefits previously reported. On the other hand, cellulosic-based reinforcements (especially the esparto wool) promoted excessive elastic buckling and, consequently, lower compression properties.

In 2015, Nasirzadeh et al. [26] carried out high velocity impact tests in order to evaluate the effect of nanoclays content (between $0 \mathrm{wt} \%$ and $3 \mathrm{wt} \%$ ) in a sandwich composed of glass fiber skins and polyurethane foam core. For this purpose, they used a gas-gun device, with a $10 \mathrm{~g}$ projectile and an initial speed of the projectile between 100 and $140 \mathrm{~m} / \mathrm{s}$. The best results were obtained with samples containing $0.5 \mathrm{wt} \%$ of nanoclays, decreasing the resistance to penetration for higher values due to the brittleness of the foam. Moreover, the agglomerations that occurred promoted weak points in the foam core [26].

To determine the effect of nanoclays content (between $0 \mathrm{wt} \%$ and $5 \mathrm{wt} \%$ ) on the dynamic thermal properties of a sandwich material, in 2016 Candan et al. [27] developed a study with a sandwich material composed by a pMDI (polymethylene diphenyl diisocyanate) resin core and wood strand skins. Sandwich samples were analyzed for viscoelastic properties using dynamic mechanical thermal analysis (DMTA). These dynamic tests were performed in dual cantilever mode (3-point bending) at a controlled heating rate of $5{ }^{\circ} \mathrm{C} / \mathrm{min}$, from $30^{\circ} \mathrm{C}$ to $180^{\circ} \mathrm{C}$, at an oscillatory frequency of $1 \mathrm{~Hz}$ and an oscillation dynamic strain of $0.01 \%$. Regardless of the storage modulus observed for $3 \mathrm{wt} \%$ of nanoclays being less than that obtained with neat resin, this value offered the best results. They also concluded that samples containing nanoclays showed lower crosslink density and greater rigidity than those with unmodified resin.

\section{Sandwich Composites Incorporating Nanoclays into the Skin}

The incorporation of nanoclays in the skin of a sandwich composite is usually done through the matrix (where the epoxy resins prevail). In this case, they increase the toughness and improve the impact performance of these materials. However, until now, few studies have focused on studying the effect of adding nanoclays on the skins.

In 2008, Kim et al. [28] developed a sandwich for stealth radome (radar + dome) applications on aircrafts and warships. These sandwiches are composed by PVC foams and skins of E-glass fabric and an epoxy resin reinforced by nanoclays. Four different contents of nanoclays, from $1 \mathrm{wt} \%$ to $4 \mathrm{wt} \%$, were used in this study. According to our best knowledge, they were the first researchers to incorporate nanoclays into the skin of a sandwich composite and to characterize its mechanical performance. For this purpose, 3-point bending tests were performed and, regardless of the nanoclays content, the flexural strength showed little variation, because the small amount of nano-fillers promoted a negligible effect on the mechanical properties of the composite. Finally, the water diffusivity decreased with the increase of nanoclays content because the diffusing water path increased by the presence of nanoclays (which have a plate-type shape).

Ávila et al. [29] produced, in 2009, sandwich panels with closed-cell PS foams (Styrofoam ${ }^{\circledR}$ ) and epoxy resin/glass fiber skins with different contents of nanoclays ( $0,1,2,5$ and $10 \mathrm{wt} \%)$ in order to improve the impact strength. For this purpose, low-velocity impact tests were performed with energies between 25 and $75 \mathrm{~J}$, which are enough to cause damage ranging from a barely visible delamination to perforation. These authors related the panel stiffness with the load-deflection response, assuming that is linear under low velocity impact, and they observed an increase in stiffness with the addition of nanoclays up to $5 \mathrm{wt} \%$ (consequently, the panel overall bending rigidity), but larger contents cause a decrease in stiffness. In this case, when the saturation is reached, it promotes agglomerations that are potential crack nucleation points. Involving similar sandwich composite plates, these authors 
developed another study in which two sets of impact tests were performed: low velocity and high mass test and high velocity and low mass test [3]. The energies applied ranged from $5 \mathrm{~J}$ to $75 \mathrm{~J}$. The results showed that the addition of $5 \mathrm{wt} \%$ of nanoclays led to the highest energy absorption, which is in line with the previous work. Simultaneously, depending of the energy level (velocity), two transitions were observed in terms of failure modes: from upper facesheet cracking plus core indentation to upper facesheet tearing plus core crushing, and from upper facesheet tearing plus core crushing to lower facesheet plus core debonding. All results were compiled by the authors in 2010 [30], where it was emphasized that the highest energy absorption was obtained with $5 \mathrm{wt} \%$ of nanoclays. A higher content of nanoclays led to immiscible nanostructures, promoting "hot spots" for cracks nucleation. According to the authors, epoxy matrices have a saturation limit between $5 \mathrm{wt} \%$ and $10 \mathrm{wt} \%$ of nanoclays [30].

In the same year, Gupta et al. [31] evaluated the impact strength and dynamic mechanical properties of vinyl ester nanocomposites incorporating nanoclays (1.25 wt \% and $2.5 \mathrm{wt} \%$ ) or exfoliated graphite nanoplatelets $(1.25 \mathrm{wt} \%$ and $2.5 \mathrm{wt} \%)$ for use in sandwich skins. Dynamic mechanical tests were performed in single cantilever deformation mode, with fixed-fixed boundary condition and temperatures between -50 and $150{ }^{\circ} \mathrm{C}$ with an increase of $3{ }^{\circ} \mathrm{C} / \mathrm{min}$, while low-velocity impact tests were performed on a drop-weight impact test machine according to the ASTM D6110-06 standard. From the dynamic mechanical tests, it was concluded that all properties (storage modulus, loss modulus, loss factor, area under $\tan \delta$ and glass transition temperature) increased with the nanoclays content, similar to that observed with graphite nanoplatelets. However, the last nano-reinforcement promoted higher improvements than those obtained with nanoclays. For example, the loss factor increased around $80 \%$ with the addition of $2.5 \mathrm{wt} \%$ of nanoclays and about $125 \%$ for the same content of graphite nanoplatelets. Regarding the impact tests, the same tendency was observed in terms of energy absorption, reaching improvements around $100 \%$ when $2.5 \mathrm{wt} \%$ of nanoclays were added [31].

In 2012, Anbusagar [32] investigated the influence of nanoclays content on sandwich composites under flexural and impact loading. Four different combinations of sandwich composites were prepared with fiber glass/nano-modified polyester skins (using $0 \mathrm{wt} \%, 2 \mathrm{wt} \%, 4 \mathrm{wt} \%$ and $6 \mathrm{wt} \%$ of nanoclays) and a polystyrene foam core. Flexural tests under three-point bending were performed to obtain the core shear stress $(\tau)$ and the skin bending stress $(\sigma)$ according to the ASTM C 393-94 standard, while the Charpy impact strength was determined according to ASTM D6110 standard. It was observed that the flexural strength and stiffness increased up to $4 \mathrm{wt} \%$ of nanoclays, with improvements of $16.3 \%$ in terms of flexural strength, while the highest impact strength was obtained with $6 \mathrm{wt} \%$ of nanoclays and with improvements of 50\% compared to the control samples.

In 2013, Reis et al. [12] studied the benefits of nano-enhanced resins on the impact response of sandwich composites produced by fiber glass/epoxy skins and balsa wood core. The epoxy resin was enhanced by nanoclays with special treatment to improve their dispersion and interface adhesion. More details about the treatment and the dispersion/exfoliation on the epoxy matrix can be found in [33]; the nanoclays content employed was $3 \mathrm{wt} \%$ of the epoxy resin/hardener mixture. Authors performed impact tests with a drop-weight testing machine and energies from 4 to $36 \mathrm{~J}$ were used. After impact tests, the residual bending strength was evaluated by three-point bending tests. It was conclude that sandwiches enhanced by nanoclays have better impact properties than the control samples [12]. For example, the benefits obtained in terms of maximum displacement were about $23.4 \%$ lower than those measured on the control samples, whereas the elastic recuperation was about $45.4 \%$ higher. Regarding the failure mechanisms, the greatest damage occurred at the highest energies and, while the control samples showed matrix cracking on both facesheets (upper and lower) with significant damage on the balsa core, the nano-enhanced sandwiches exhibited damage only on the upper facesheet. Moreover, as shown in Figure 2, the neat sandwiches showed lower residual flexural strength for all impact energies, because the nanofillers increase the stiffness of the facesheets and, consequently, the panel overall bending stiffness. 


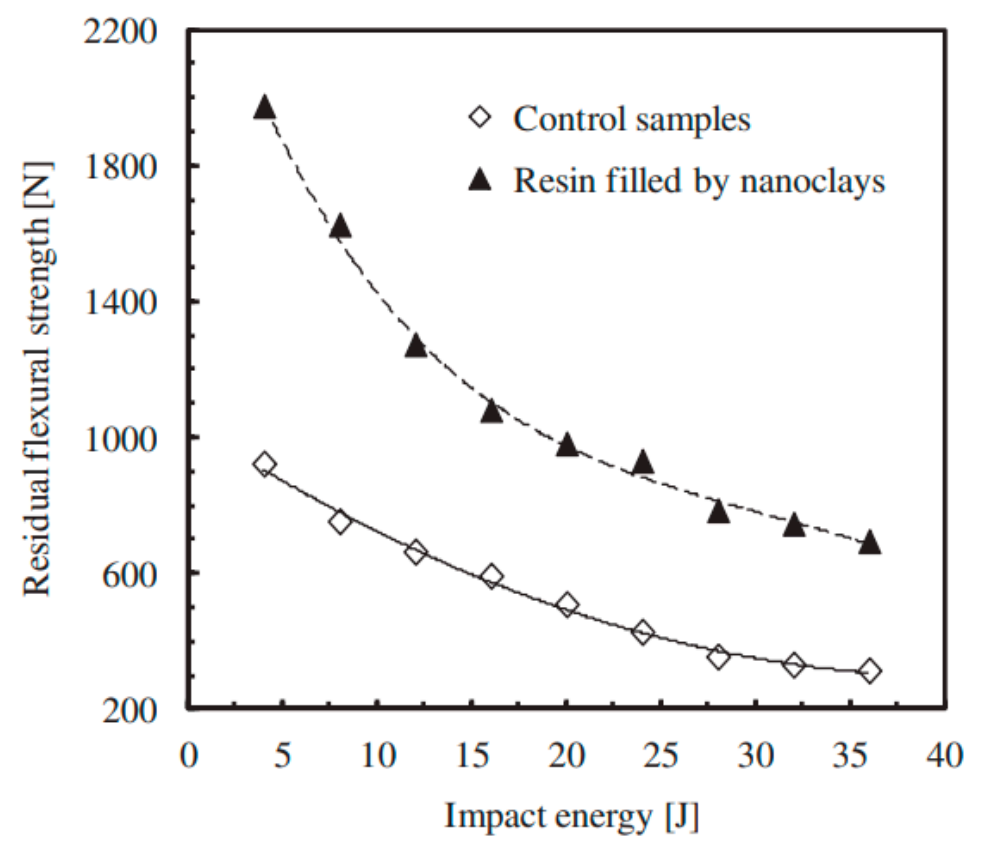

Figure 2. Residual flexural strength versus impact energy [12].

In 2014, Anbusagar et al. [34] evaluated the effect of nanoclays modified polyester resin on flexural, impact, hardness and water absorption properties of jute and glass fabric hybrid sandwich laminates. For this purpose, contents of $2 \mathrm{wt} \%, 4 \mathrm{wt} \%$ and $6 \mathrm{wt} \%$ of nanoclays were used. It was possible to conclude that both the flexural strength and the flexural modulus increased up to $4 \mathrm{wt} \%$ of nano-reinforcements, but no additional increase was observed for higher contents. In this case, the benefits obtained are $90 \%$ and $67 \%$ higher than the strength and modulus of the neat jute laminate (100 $\mathrm{wt} \%$ of jute fibers), respectively. Regarding the impact strength, hardness and water absorption, the optimum loading was $6 \mathrm{wt} \%$ of nanoclays. For example, the impact strength increased around 5.5 times the value obtained for neat jute laminates (100 $\mathrm{wt} \%$ of jute fibers), the hardness increased around $27 \%$ compared to the value obtained for composite laminates ( $60 \mathrm{wt} \%$ of jute fibers plus $40 \mathrm{wt} \%$ of glass fiber). The maximum percentage of moisture absorption after $744 \mathrm{~h}$ of soaking decreased by 1.5 times the value obtained for neat composite laminates. This was explained due to impermeable fillers, like clay and glass fibers, which act as barriers and prevent the direct contact between jute and water [34].

In 2014, Puggal et al. [35] analyzed the benefits obtained with nanoclays in a sandwich structure composed of bidirectional E-glass fiber, epoxy resin and high density thermocol. For this purpose, experimental tests were carried out in tensile and flexural mode and the amounts of nanoclays dispersed into the epoxy resin were 1,3 and $5 \mathrm{wt} \%$. It was observed that the mechanical properties obtained increased with increasing the nanoclays content, but while the maximum tensile strength was achieved with $3 \mathrm{wt} \%$ of nanoclays ( $33 \%$ higher compared to the control samples), the maximum bending strength was achieved with $5 \mathrm{wt} \%$ of nanoclays ( $47.8 \%$ higher compared to the control samples). The bending strength was also obtained after immersion into water for 15 days and, while the decrease compared with the dry samples was $13.8 \%$ for control samples (neat resin), this value was only $4.2 \%$ for composites reinforced with $5 \mathrm{wt} \%$ of nanoclays. In fact, the weight gain was about $3.2 \%$ for neat samples, while for composites enhanced with $5 \mathrm{wt} \%$ of nanoclays was only $1.6 \%$.

Later, in 2015, Anbusagar et al. [36] gave continuity to previous studies and, using similar sandwich laminates (described in ref. [32]), evaluated the influence of nanoclays content on flexural, impact and water absorption properties. Initially, they studied only the fiber reinforced polymer (FRP) used in the skins and, for that purpose, flexural tests were carried out. They noticed that the flexural properties started to decrease after $4 \mathrm{wt} \%$ of nanoclays, therefore, only $0 \mathrm{wt} \%$ and $4 \mathrm{wt} \%$ of nanoclays 
were used to analyze the sandwich laminates. In this case, when $4 \mathrm{wt} \%$ of nanoclays were added to the FRP laminates, improvements of $40 \%$ and $57 \%$ were achieved in terms of bending strength and bending modulus, respectively. Regarding the sandwich laminates, the benefits obtained were about $60.4 \%$ and 21.8 times higher than the values obtained with the neat FRP laminate (fiber glass/polyester resin), respectively. From the Charpy impact tests carried out with a velocity of $0.75 \mathrm{~m} / \mathrm{s}$, it was possible to conclude that the impact strength of sandwich laminate was $43 \%$ higher over the FRP laminate. Finally, the maximum percentage of moisture absorption after $744 \mathrm{~h}$ was about $5 \%$ for neat sandwich laminates and $4 \%$ for sandwich laminates with $4 \mathrm{wt} \%$ of nanoclays [36].

In 2016, Syakir et al. [37] compared the mechanical properties of two sandwich composites. One of them was composed of glass fiber skin and jute core and the other one by glass fiber skin and PS-foam core. The matrix used was a polyester resin, in which 2,4 and $6 \mathrm{wt} \%$ of nanoclays were added. In terms of flexural properties, it was noticed an increase with the percentage of nano-reinforcements, reaching the maximum values with $4 \mathrm{wt} \%$ of nanoclays. Compared to the neat samples, improvements of $16 \%$ and $19.5 \%$ were observed in terms of flexural strength for jute sandwiches and PS-foam sandwiches, respectively, while these values for the flexural modulus were around $45 \%$ and $42 \%$, respectively. Regardless of the same trend observed for the Charpy impact strength and water absorption, in this case, the most significant improvements were achieved for $6 \mathrm{wt} \%$ of nanoclays. Therefore, comparatively to the neat samples, the Charpy impact strength increases around $22.4 \%$ and $49 \%$ for the jute sandwiches and PS-foam sandwiches, respectively, whereas the reduction in water absorption was more than $50 \%$ and $72 \%$ of the values observed for jute sandwiches and PS-foam sandwiches, correspondingly. In this case, the higher water permeability of the PS-foam core in comparison with the jute core must be emphasized. Moreover, from the low velocity impact tests carried out with an energy of $10 \mathrm{~J}$, these authors observed damage areas $24 \%$ lower and 2.2 times lower, respectively, for jute sandwiches and PS-foam sandwiches reinforced with $4 \mathrm{wt} \%$ of nanoclays. Consequently, the post impact compression strength and modulus were $44 \%$ and $87 \%$ higher for jute sandwiches and $38 \%$ and $41 \%$ higher for PS-foam sandwiches, respectively.

More recently, in 2018, Anbusagar et al. [38] carried out low velocity impact tests (using a weight-drop impact machine) on sandwich composites similar to those described in ref. [32] and [34]. The impact energy used in this study was $30 \mathrm{~J}$ and, as reported in [33], only neat sandwich composites and sandwich composites reinforced by $4 \mathrm{wt} \%$ of nanoclays were analyzed. It was possible to conclude that all parameters obtained from the impact tests are very similar between both sandwiches. For example, the peak load was only 2.2\% higher than the value obtained for the neat sandwich, while the displacement and absorbed energy were $4.2 \%$ and $2.5 \%$ lower, respectively. On the other hand, considering the damage degree, which is defined as the ratio between the energy absorbed and the energy of impact (less than one up to incursion and equal to one when it occurs), this parameter reached the minimum value (0.24) for nano-enhanced sandwiches. These results clearly evidence the benefits obtained with nano-enhanced resins. Although the damage caused by the impact load is not visible in both sandwiches, authors evaluated the residual bending properties using four-point bending tests. For comparability, they evaluated the pre- and post-impact flexural properties. While the non-impacted samples showed values of strength and stiffness around $7.2 \%$ and $66.3 \%$ higher than those obtained for neat sandwich composites, after impact they are about $3.5 \%$ and $80 \%$, respectively. This means that, after impact, the strength and stiffness decreased by $13.8 \%$ and $12.2 \%$, respectively, for neat sandwiches, while these values are $16.7 \%$ and $4.9 \%$ for nano-reinforced sandwiches.

Finally, in 2019, Anbusagar et al. [39] gave continuity to another study, where the effect of modified nanoclays on low velocity impact damage area and damage tolerance capability was analyzed using sandwich laminates similar to those described in ref. [34]. For this purpose, low velocity impact tests were performed with impact energies of $10 \mathrm{~J}$ and $20 \mathrm{~J}$ and compression after impact (CAI) tests were carried out in order to evaluate the residual compressive strength and residual compressive stiffness of the sandwich laminates. The damage areas were estimated and a decrease of $19.5 \%$ and $13.5 \%$ was observed for the energies of $10 \mathrm{~J}$ and $20 \mathrm{~J}$, respectively, when $6 \mathrm{wt} \%$ of nanoclays were added 
to the resin. Matrix cracking is the main damage mechanism observed in laminates involving only jute fibers (for $10 \mathrm{~J}$ the damage is not significantly visible on the bottom face of the laminate, but for $20 \mathrm{~J}$ it is visible on both sides due to fiber breakage and cracks in the matrix), while in hybrid sandwich laminates, delamination is the predominant mode of failure with the beginning between the jute core and the fiber glass skin interface. It was also observed that the residual compressive strength is very low for laminates involving only jute fibers and the damage tolerance capability improved with the incorporation of glass fibers and nanoclays reinforcement in the hybrid sandwich laminates. For example, the residual compressive strength for hybrid sandwiches with $6 \mathrm{wt} \%$ of nanoclays increased about 3.5 times over the laminates involving only jute fibers.

\section{Synthetic Summary for an Overview of the Benefits Obtained with Nanoclay Reinforcements}

A review of all published works is presented in the previous section, where the benefits obtained with nanoclays are reported in detail. It is possible to conclude that the content of nanoclays varies significantly to maximize a specific property of sandwich composites. In fact, the mechanical properties depend not only on the clay content, but also on the type of resin and manufacturing process [40]. Ávila et al. [30], for example, report that epoxy matrices have a saturation limit between $5 \mathrm{wt} \%$ and $10 \mathrm{wt} \%$ of nanoclays. Therefore, a high content of nanoclays leads to immiscible nanostructures, promoting, in this case, "hot spots" for cracks nucleation. On the other hand, montmorillonite (MMT) clays generally contain impurities and a wide particles size distribution, which causes high dispersion in the mechanical and physical properties of polymeric nanocomposites [40].

However, regardless of this remark, this section intends to summarize the main benefits, in terms of mechanical performance, obtained with the addition of nanoclays into sandwich composites, both to the level of their cores (Table 1) and their skins (Table 2).

Table 1. Summary of the benefits obtained with nanoclays added to the cores.

\begin{tabular}{|c|c|c|c|c|c|c|}
\hline Year & Author & $\begin{array}{l}\text { Sandwich } \\
\text { (Skin/Core) }\end{array}$ & $\begin{array}{l}\text { Type of } \\
\text { Nanoclay }\end{array}$ & $\begin{array}{l}\text { Wt } \% \text { of } \\
\text { Nanoclay }\end{array}$ & Improvements & Ref. \\
\hline 2005 & Gupta et al. & Syntactic foam & MMT & 2 and 5 & $\begin{array}{l}\text { Toughness around } 80 \% \text { and } 125 \% \text { for } \\
\text { low density foams, } 150 \text { and } 200 \% \text { for } \\
\text { medium density and } 125 \% \text { for high } \\
\text { density foams for } 2 \mathrm{wt} \% \text { and } 5 \mathrm{wt} \% \\
\text { of } \mathrm{NC}^{*} \text {, respectively. }\end{array}$ & [13] \\
\hline 2008 & Saha et al. & $\begin{array}{c}\text { Glass } \\
\text { fiber/polyurethane } \\
\text { foam core }\end{array}$ & $\mathrm{NF}^{* *}$ & 0.5 to 1.5 & $\begin{array}{l}\text { The fracture toughness is } 69 \% \text { higher } \\
\text { with } 1 \mathrm{wt} \% \text { of } \mathrm{NC}^{*} \text { compared to the } \\
\text { neat foam core. }\end{array}$ & [14] \\
\hline 2008 & Hosur et al. & $\begin{array}{l}\text { Carbon fiber/PU } \\
\text { foam }\end{array}$ & MMT & 0.5 to 2 & $\begin{array}{l}\text { Nanophased foams pre-sent higher } \\
\text { loads and lower damage areas. }\end{array}$ & [15] \\
\hline 2008 & Robinson et al. & PU foam & $\begin{array}{l}\text { MMT, Nanocor } \\
\text { I }^{\circledR} 28 \mathrm{E}\end{array}$ & 0.5 to 2 & $\begin{array}{l}0.5 \mathrm{wt} \% \text { and } 1 \mathrm{wt} \% \mathrm{NC} * \text { infused } \\
\text { foams have the best storage modulus } \\
\text { and glass transition temperatu-res. } \\
\text { The same values pro-moted the best } \\
\text { compressi-ve strength and modulus, } \\
\text { as well as the best flexural strength. }\end{array}$ & [16] \\
\hline 2009 & Saha et al. & Syntactic foam & MMT & 1 to 3 & $\begin{array}{l}\text { The highest properties we-re } \\
\text { obtained with } 2 \text { wt } \% \text { of NC } \text { N }^{*} 42 \% \text { in } \\
\text { terms of ben-ding strength and } 18 \% \\
\text { in bending modulus, as well as } 30 \% \\
\text { in storage modulus and } 28 \% \text { in loss } \\
\text { modulus, when compared to the neat } \\
\text { syntactic foams). }\end{array}$ & [17] \\
\hline 2009 & $\begin{array}{l}\text { Woldensenbet } \\
\text { et al. }\end{array}$ & Syntactic foam & MMT & 1 & $\begin{array}{l}\text { An increase in the core shear stress } \\
\text { and facing bending stress was } \\
\text { obser-ved in three-point and } \\
\text { four-point bending tests when NC * } \\
\text { was added. }\end{array}$ & [18] \\
\hline
\end{tabular}


Table 1. Cont.

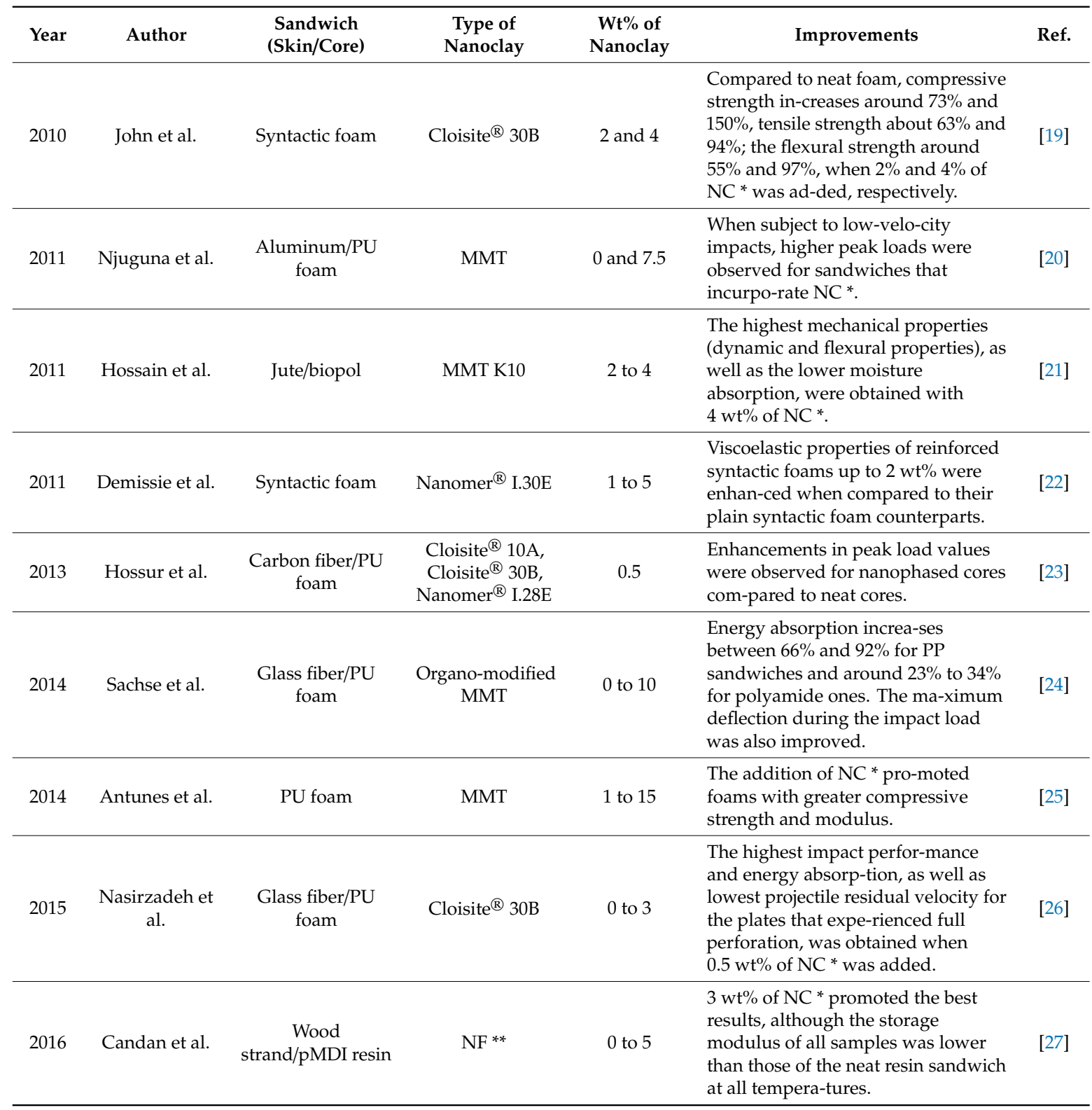

${ }^{*} \mathrm{NC}-$ Nanoclay; ${ }^{* *} \mathrm{NF}-\mathrm{Not}$ mentioned.

Table 2. Summary of the benefits obtained with nanoclays added to the skins.

\begin{tabular}{|c|c|c|c|c|c|c|}
\hline Year & Author & $\begin{array}{l}\text { Sandwich } \\
\text { (Skin/Core) }\end{array}$ & $\begin{array}{c}\text { Type of } \\
\text { Nanoclay }\end{array}$ & $\begin{array}{c}\text { Wt\% of } \\
\text { Nanoclay }\end{array}$ & Improvements & Ref. \\
\hline 2008 & Kim et al. & E-glass/PVC foam & Cloisite $^{\circledR}$ 93A & 1 to 4 & $\begin{array}{l}\text { The water diffusivity decrea-sed around } \\
40 \% \text { when } 3 \mathrm{wt} \% \text { of } \mathrm{NC} * \text { was added to } \\
\text { the resin. }\end{array}$ & [28] \\
\hline 2009 & Ávila et al. & $\begin{array}{l}\text { Glass fiber/PS } \\
\text { foam }\end{array}$ & Cloisite ${ }^{\circledR} 30 \mathrm{~B}$ & 0 to 5 & $\begin{array}{l}\text { The energy absorption and failure } \\
\text { mechanisms changed when } \mathrm{NC}^{*} \text { was } \\
\text { added. The best value for } \mathrm{NC}^{*} \text { content } \\
\text { was } 5 \mathrm{wt} \% \text {. }\end{array}$ & [29] \\
\hline 2009 & Ávila et al. & $\begin{array}{c}\text { Glass } \\
\text { fiber/polystyrene }\end{array}$ & Cloisite $^{\circledR}$ 30B & 0 to 10 & $\begin{array}{l}\text { The addition of } 5 \mathrm{wt} \% \text { of } \mathrm{NC} * \text { promoted } \\
\text { more efficient ener-gy absorption and } \\
\text { different failure modes. }\end{array}$ & [3] \\
\hline 2010 & Avila et al. & $\begin{array}{l}\text { Glass fiber/PS } \\
\text { foam }\end{array}$ & Cloisite $^{\circledR}$ 30B & 0 to 10 & $\begin{array}{l}\text { The addition of } 5 \mathrm{wt} \% \text { of } \mathrm{NC} * \text { promoted } \\
\text { more efficient ener-gy absorption and } \\
\text { different failure modes when } \mathrm{NC}^{*} \text { was } \\
\text { added to face sheets. }\end{array}$ & [30] \\
\hline
\end{tabular}


Table 2. Cont.

\begin{tabular}{|c|c|c|c|c|c|c|}
\hline Year & Author & $\begin{array}{l}\text { Sandwich } \\
\text { (Skin/Core) }\end{array}$ & $\begin{array}{c}\text { Type of } \\
\text { Nanoclay }\end{array}$ & $\begin{array}{c}\text { Wt } \% \text { of } \\
\text { Nanoclay }\end{array}$ & Improvements & Ref. \\
\hline 2010 & Gupta et al. & Vinyl ester/foam & Cloisite $^{\circledR}$ 30B & 1.25 to 2.5 & $\begin{array}{l}\text { Storage modulus, loss factor and loss } \\
\text { modulus increased for higher contents of } \\
\mathrm{NC}^{*} \text {. }\end{array}$ & [31] \\
\hline 2012 & $\begin{array}{c}\text { Anbusagar } \\
\text { et al. }\end{array}$ & $\begin{array}{l}\text { Glass fiber/PS } \\
\text { foam }\end{array}$ & Cloisite ${ }^{\circledR} \mathrm{Na}+$ & 2 to 6 & $\begin{array}{l}4 \mathrm{wt} \% \text { of } \mathrm{NC} * \text { promoted the highest } \\
\text { flexural properties and } 6 \mathrm{wt} \% \text { increased } \\
\text { the impact strength by around } 50 \% \text {. }\end{array}$ & [32] \\
\hline 2013 & Reis et al. & $\begin{array}{c}\text { Glass fiber/balsa } \\
\text { wood }\end{array}$ & Cloisite $^{\circledR}$ 30B & 3 & $\begin{array}{l}\text { Lower displacements }(23.4 \%) \text { and higher } \\
\text { elastic recuperation }(45.4 \%) \text { occurred for } \\
\text { sandwi-ches with resin nano-enhan-ced. } \\
\text { Residual flexural strength increased with } \\
\text { the introduc-tion of NC *. }\end{array}$ & [12] \\
\hline 2014 & $\begin{array}{l}\text { Anbusagar } \\
\text { et al. }\end{array}$ & $\begin{array}{c}\text { Glass fiber/jute } \\
\text { fiber }\end{array}$ & $\begin{array}{c}\mathrm{Na}+ \\
\text { Montmorillonite }\end{array}$ & 0 to 6 & $\begin{array}{l}\text { The highest flexural properties were } \\
\text { obtained for } 4 \% \text { of NC } * \text {, while the } \\
\text { impact, hardness and water absorption } \\
\text { properties were obtained for } 6 \% \text { of NC } *\end{array}$ & [34] \\
\hline 2014 & Puggal et al. & $\begin{array}{l}\text { Glass } \\
\text { fiber/thermocol }\end{array}$ & Cloisite $^{\circledR}$ 30B & 1 to 5 & $\begin{array}{l}\text { Tensile strength increased about } 33 \% \\
\text { when } 3 \% \text { of NC * was added. Regarding } \\
\text { the flexural properties, the ben-ding } \\
\text { strength increased around } 47 \% \text { when } 5 \% \\
\text { of NC }{ }^{*} \text { was ad-ded. Water absorption } \\
\text { decrea-sed for samples with NC } *\end{array}$ & [35] \\
\hline 2015 & $\begin{array}{c}\text { Anbusagar } \\
\text { et al. }\end{array}$ & $\begin{array}{l}\text { Glass fiber/PS } \\
\text { foam }\end{array}$ & Cloisite ${ }^{\circledR} \mathrm{Na}+$ & 0 to 4 & $\begin{array}{l}4 \mathrm{wt} \% \text { of } \mathrm{NC} * \text { was the best content to } \\
\text { obtain the highest flexural properties } \\
\text { (improve-ments about } 60 \% \text { and } 21 \% \text { for } \\
\text { the flexural strength and stiff-ness, } \\
\text { respectively) and Charpy impact } \\
\text { strength (improve-ments around } 43 \% \text { ). }\end{array}$ & [36] \\
\hline 2016 & $\begin{array}{c}\text { Anbu Sagar } \\
\text { et al. }\end{array}$ & $\begin{array}{l}\text { Glass fiber/jute } \\
\text { fiber }\end{array}$ & $\begin{array}{c}\mathrm{Na}+ \\
\text { Montmorillonite }\end{array}$ & 2 to 6 & $\begin{array}{l}4 \mathrm{wt} \% \text { of } \mathrm{NC}{ }^{*} \text { was the best content to } \\
\text { obtain the highest flexural properties } \\
\text { (improve-ments about } 16.2 \% \text { and } 44.9 \% \\
\text { for the flexural strength and stiffness, } \\
\text { respectively). } 6 \mathrm{wt} \% \text { of } \mathrm{NC}{ }^{*} \text { was the } \\
\text { best content to obtain the highest Charpy } \\
\text { impact strength (improve-ments around } \\
22.4 \% \text { ) and moisture absorption of } 50 \% \\
\text { after } 744 \mathrm{~h} \text {. }\end{array}$ & [37] \\
\hline 2016 & $\begin{array}{c}\text { Anbu Sagar } \\
\text { et al. }\end{array}$ & $\begin{array}{l}\text { Glass fiber/PS } \\
\text { foam }\end{array}$ & $\begin{array}{c}\mathrm{Na}+ \\
\text { Montmorillonite }\end{array}$ & 2 to 6 & $\begin{array}{l}4 \mathrm{wt} \% \text { of } \mathrm{NC}{ }^{*} \text { was the best content to } \\
\text { obtain the highest flexural properties } \\
\text { (improve-ments about } 19.5 \% \text { and } 42 \% \\
\text { for the flexural strength and stiffness, } \\
\text { respectively). } 6 \mathrm{wt}^{\circ} \% \text { of } \mathrm{NC}{ }^{*} \text { was the } \\
\text { best content to obtain the highest Charpy } \\
\text { impact strength (improve-ments around } \\
50 \% \text { ) and moisture absorption of } 72 \% \\
\text { after } 744 \mathrm{~h} \text {. }\end{array}$ & [37] \\
\hline 2018 & $\begin{array}{c}\text { Anbusagar } \\
\text { et al. }\end{array}$ & $\begin{array}{l}\text { Glass fiber/PU } \\
\text { foam }\end{array}$ & $\begin{array}{c}\mathrm{Na}+ \\
\text { Montmorillonite }\end{array}$ & 4 & $\begin{array}{l}4 \mathrm{wt} \% \text { of } \mathrm{NC} * \text { increased the load } \\
\text { carrying capacity around } 114 \% \text { higher } \\
\text { than for control samples. Decreased the } \\
\text { defle-ction damage during the im-pact. } \\
\text { After impact, flexural strength and } \\
\text { bending stiffness increased } 23 \% \text { and } 40 \% \text {, } \\
\text { res-pecttively. }\end{array}$ & [38] \\
\hline 2019 & $\begin{array}{c}\text { Anbusagar } \\
\text { et al. }\end{array}$ & $\begin{array}{l}\text { Glass fiber/jute } \\
\text { fiber }\end{array}$ & $\begin{array}{l}\text { Organically } \\
\text { modified } \\
\text { Montmorillonite }\end{array}$ & 0 to 6 & $\begin{array}{l}6 \mathrm{wt} \% \text { of } \mathrm{NC} * \text { showed a decrease in } \\
\text { damage area close to } 19.5 \% \text {, for low } \\
\text { energies and } 15.5 \% \text { for medium energies. } \\
\text { The damage tolerance capabi-lity } \\
\text { increased about } 3.5 \text { times. }\end{array}$ & [39] \\
\hline
\end{tabular}

* NC-Nanoclay.

\section{Conclusions}

Literature presents a considerable number of studies reporting the advances achieved in the field of sandwich materials, in order to respond to the countless industrial applications that we have witnessed 
in recent years. In order to increase the mechanical performance of these materials, nanoclays is suggested in the bibliography as the most popular nano-reinforcements for polymeric nanocomposites due their relatively high ion exchange capacity, high aspect ratio and economic advantages.

The studies described in the present document showed that the use of nanoclays improve, in general, the mechanical properties of the sandwich materials, but with especial incidence on the impact performance independently of it being used in the skin layer or in the core layer. It is possible to conclude that the mechanical properties are dependent, not only of the clays content but, also, of the resin type and manufacturing process. However, the highest mechanical properties are obtained with a good dispersion and full exfoliation of the nanoclays into matrix. For example, depending on the sandwich architecture, literature report improvements on the dynamic properties around $30 \%$ at level of the storage modulus and $28 \%$ on the loss modulus. In comparison with sandwiches without nanoclays, benefits between $73 \%$ and $150 \%$ are obtained in terms of compressive strength and between $33 \%$ and $94 \%$ for tensile strength. Similarly, the bending properties increase between $16.2 \%$ and $97 \%$ as well as $18 \%$ and $44.9 \%$ in terms of bending strength and bending modulus, respectively. Depending on the foams' density, the benefits observed in fracture toughness are between $69 \%$ and $200 \%$, while the Charpy impact strength reaches values between $22.4 \%$ and $50 \%$. In terms of properties obtained by impact drop weight tests, it is possible to observe higher load carrying capacity, lower displacements and higher elastic recuperation for sandwiches with nanoenhanced resins. Simultaneously, higher residual mechanical properties are obtained. All the benefits that were previously reported are explained by the change of failure mechanisms when nanoclays are added. On the other hand, nanoclays dispersed in the matrix decrease the mean free path of water molecules to pass through the nanocomposite network compared to the pure matrix, which leads to lower water absorption. In this context, decreases between $50 \%$ and $72 \%$ of water absorption are observed in the literature for sandwich materials when nanoclays are added.

However, future research works should be focus in the fatigue behavior of this material, as well as in the study on the mechanical and impact performances of the material with an optimal addition of nanoclay in both skin and core layers, in order to see if there is a multiplying effect on that kind of addition.

Author Contributions: J.P. and P.N.B.R. conceived and designed the study. J.P., P.N.B.R., M.N. and A.M.A., participated in the research work and in the draft of the manuscript. J.P., P.N.B.R., M.N. and A.M.A., read and approved the final manuscript. All authors have read and agreed to the published version of the manuscript.

Funding: This work was supported by the project Centro-01-0145-FEDER-000017-EMaDeS-Energy, Materials and Sustainable Development and co-financed by the Portugal 2020 Program (PT 2020), within the Regional Operational Program of the Center (CENTRO 2020) and the European Union through the European Regional Development Fund (ERDF).

Acknowledgments: This research was sponsored by FEDER funds through the program COMPETE-Programa Operacional Factores de Competitividade, and by national funds through FCT-Fundação para a Ciência e a Tecnologia, under Project UID/EMS/00285/2020.

Conflicts of Interest: The authors declare no conflict of interest.

\section{References}

1. Chai, G.B.; Zhu, S. A review of low-velocity impact on sandwich structures. Proc. Inst. Mech. Eng. Part L J. Mater. Des. Appl. 2011, 225, 207-230. [CrossRef]

2. Zenkert, D. The Handbook of Sandwich Construction; Engineering Materials Advisory Services Ltd.: Worcestershire, UK, 1997.

3. Avila, A.; Andrade, M.; Cruz, D.; Sousa, D.; Dias, E. Nano-Modified Sandwich Composites Under Dynamic Loading Conditions. In Proceedings of the 50th AIAA/ASME/ASCE/AHS/ASC Structures, Structural Dynamics, and Materials Conference, Palm Springs, CA, USA, 4-7 May 2009; pp. 1-13. [CrossRef]

4. Ogorkiewicz, R.M. Analysis and design of structural sandwich panels. Composites 1970, 1, 378. [CrossRef]

5. Steeves, C.A.; Fleck, N.A. Material selection in sandwich beam construction. Scr. Mater. 2004, 50, 1335-1339. [CrossRef] 
6. Safri, S.; Sultan, M.; Yidris, N.; Mustapha, F. Low Velocity and High Velocity Impact Test on Composite Materials-A review. Int. J. Eng. Sci. 2014, 3, 50-60.

7. Cantwell, W.J.; Morton, J. The impact resistance of composite materials-A review. Composites 1991, 22, 347-362. [CrossRef]

8. Daniel, I.M.; Gdoutos, E.E.; Rajapakse, Y.D.S. (Eds.) Major Accomplishments in Composite Materials and Sandwich Structures; Springer: Dordrecht, The Netherlands, 2010.

9. Ibrahim, M.E. Nondestructive evaluation of thick-section composites and sandwich structures: A review. Compos. Part A Appl. Sci. Manuf. 2014, 64, 36-48. [CrossRef]

10. Atas, C.; Sevim, C. On the impact response of sandwich composites with cores of balsa wood and PVC foam. Compos. Struct. 2010, 93, 40-48. [CrossRef]

11. Rafiee, R.; Shahzadi, R. Mechanical Properties of Nanoclay and Nanoclay Reinforced Polymers: A Review. Polym. Compos. 2019, 40, 431-445. [CrossRef]

12. Reis, P.; Santos, P.; Ferreira, J.; Richardson, M. Impact response of sandwich composites with nano-enhanced epoxy resin. J. Reinf. Plast. Compos. 2013, 32, 898-906. [CrossRef]

13. Gupta, N.; Maharsia, R. Enhancement of Energy Absorption in Syntactic Foams by Nanoclay Incorporation for Sandwich Core Applications. Appl. Compos. Mater. 2005, 12, 247-261. [CrossRef]

14. Saha, M.C.; Kabir, E.; Jeelani, S. Study of debond fracture toughness of sandwich composites with nanophased core. Mater. Lett. 2008, 62, 567-570. [CrossRef]

15. Hosur, M.V.; Mohammed, A.A.; Zainuddin, S.; Jeelani, S. Processing of nanoclay filled sandwich composites and their response to low-velocity impact loading. Compos. Struct. 2008, 82, 101-116. [CrossRef]

16. Robinson, D.C.; Hosur, M.V.; Jeelani, S. Processing and performance of nanoclay infused low density polyurethane foams. In Proceedings of the International SAMPE Technical Conference, Long Beach, CA, USA, 18-22 May 2008.

17. Saha, M.C.; Nilufar, S. Nanoclay-reinforced syntactic foams: Flexure and thermal behavior. Polym. Compos. 2009, 31, 1332-1342. [CrossRef]

18. Woldensenbet, E.; Sankella, N. Flexural Properties of Nanoclay Syntactic Foam Sandwich Structures. J. Sandw. Struct. Mater. 2009, 11, 425-444. [CrossRef]

19. John, B.; Nair, C.P.R.; Ninan, K.N. Effect of nanoclay on the mechanical, dynamic mechanical and thermal properties of cyanate ester syntactic foams. Mater. Sci. Eng. A 2010, 527, 5435-5443. [CrossRef]

20. Njuguna, J.; Michałowski, S.; Pielichowski, K.; Kayvantash, K.; Walton, A.C. Fabrication, characterization and low-velocity impact testing of hybrid sandwich composites with polyurethane/layered silicate foam cores. Polym. Compos. 2011, 32, 6-13. [CrossRef]

21. Hossain, M.K.; Dewan, M.W.; Hosur, M.; Jeelani, S. Mechanical performances of surface modified jute fiber reinforced biopol nanophased green composites. Compos. Part B Eng. 2011, 42, 1701-1707. [CrossRef]

22. Demissie, B.; John, M.; Woldesenbet, E. High strain rate behavior of hygrothermally conditioned syntactic foams for marine applications. In Proceedings of the ICCM International Conferences on Composite Materials, Jeju Island, Korea, 21-26 August 2011; pp. 1-5.

23. Hosur, M.; Strawder, G.; Jeelani, S. Low-Velocity Impact Response of Sandwich Composites with FRP Facesheets and Nanoclay-Wood Flour Modified Polyurethane Foam. In Proceedings of the 8th Pacific Rim International Congress on Advanced Materials and Processing; Springer International Publishing: Cham, Switzerland, 2013; Volume 2, pp. 1441-1446.

24. Sachse, S.; Poruri, M.; Silva, F.; Michalowski, S.; Pielichowski, K.; Njuguna, J. Effect of nanofillers on low energy impact performance of sandwich structures with nanoreinforced polyurethane foam cores. J. Sandw. Struct. Mater. 2014, 16, 173-194. [CrossRef]

25. Antunes, J.I.V.M.; Cano, Á.; Realinho, V.; Arencón, D. Compression properties and cellular structure of polyurethane composite foams combining nanoclay and different reinforcements. Int. J. Compos. Mater. 2014, 4, 27-34. [CrossRef]

26. Nasirzadeh, R.; Sabet, A.R. Influence of nanoclay reinforced polyurethane foam toward composite sandwich structure behavior under high velocity impact. J. Cell. Plast. 2016, 52, 253-275. [CrossRef]

27. Candan, Z.; Gardner, D.J.; Shaler, S.M. Dynamic mechanical thermal analysis (DMTA) of cellulose nanofibril/nanoclay/pMDI nanocomposites. Compos. Part B Eng. 2016, 90, 126-132. [CrossRef]

28. Kim, P.C.; Lee, D.G.; Seo, I.S.; Kim, G.H. Nanocomposite stealth radomes with frequency selective surfaces. Compos. Struct. 2008, 86, 299-305. [CrossRef] 
29. Ávila, A.F.; Andrade, M.C.; Dias, E.C.; Cruz, D.T.L. Nanosandwich' structures under impact loadings. In Proceedings of the ICCM International Conference on Composite Materials, Edinburgh, UK, 27-31 July 2009.

30. Ávila, A.F.; Carvalho, M.G.R.; Dias, E.C.; da Cruz, D.T.L. Nano-structured sandwich composites response to low-velocity impact. Compos. Struct. 2010, 92, 745-751. [CrossRef]

31. Gupta, S.; Mantena, P.R.; Al-Ostaz, A. Dynamic Mechanical and Impact Property Correlation of Nanoclay and Graphite Platelet Reinforced Vinyl Ester Nanocomposites. J. Reinf. Plast. Compos. 2010, 29, 2037-2047. [CrossRef]

32. Anbusagar, N.R.R.; Giridharan, P.K.; Palanikumar, K. Influence of Nano Particle on Flexural and Impact Properties of Sandwich Structures. Adv. Mater. Res. 2012, 602-604, 174-177. [CrossRef]

33. Reis, P.N.B.; Ferreira, J.A.M.; Santos, P.; Richardson, M.O.W.; Santos, J.B. Impact response of Kevlar composites with filled epoxy matrix. Compos. Struct. 2012, 94, 3520-3528. [CrossRef]

34. Anbusagar, N.; Giridharan, P.K.; Palanikumar, K. Effect of nanomodified polyester resin on hybrid sandwich laminates. Mater. Des. 2014, 54, 507-514. [CrossRef]

35. Puggal, S.; Mahajan, S.; Dhall, N. A study on glass fiber reinforced polymer-clay nanocomposites with sandwich structure. Int. J. Res. Eng. Technol. 2014, 3, 194-198. [CrossRef]

36. Anbusagar, N.; Palanikumar, K.; Giridharan, P.K. Study of sandwich effect on nanoclay modified polyester resin GFR face sheet laminates. Compos. Struct. 2015, 125, 336-342. [CrossRef]

37. Sagar, N.R.R.A.; Palanikumar, K. Development and Characterization of Nano Clay Reinforced Three-Phase Sandwich Composite Laminates. In Nanoclay Reinforced Polymer Composites; Jawaid, M., Qaiss, A.E., Bouhfid, R., Eds.; Springer: Singapore, 2016; pp. 357-391.

38. Anbusagar, N.R.R.; Palanikumar, K. Nanoclay Addition and Core Materials Effect on Impact and Damage Tolerance Capability of Glass Fiber Skin Sandwich Laminates. Silicon 2018, 10, 769-779. [CrossRef]

39. Anbusagar, N.; Palanikumar, K.; Ramulu, P.J. Study of Damage Mechanism on OMT Nanoclay Polymer Hybrid Sandwich Laminates. Mater. Today Proc. 2019, 16, 262-267. [CrossRef]

40. Ferreira, J.A.M.; Reis, P.N.B.; Costa, J.D.M.; Capela, C. Assessment of the mechanical properties of nanoclays enhanced low Tg epoxy resins. Fibers Polym. 2014, 15, 1677-1684. [CrossRef]

(C) 2020 by the authors. Licensee MDPI, Basel, Switzerland. This article is an open access article distributed under the terms and conditions of the Creative Commons Attribution (CC BY) license (http://creativecommons.org/licenses/by/4.0/). 